\title{
ERRATUM
}

\section{KEYNES, MILL, AND SAY'S LAW: A COMMENT ON ROY GRIEVE'S MISTAKEN CRITICISMS OF MILL - ERRATUM}

\author{
BY \\ JAMES C. W. AHIAKPOR
}

doi: 10.1017/S1053837217000281, Published by Cambridge University Press, 24 May 2018.

In the original publication of this article, there were errors in two citations in the fourth paragraph of page 269. The following is the corrected text with the proper citations:

Furthermore, Mill recognizes that "the future presents nothing which can be with certainty either foreseen or governed" (1965, 2, p. 165). Yet, Grieve repeats Keynes's ([1936] 1974, p. 24n3) misrepresentation of the proponents of Say's Law, including Mill, of not being cognizant of uncertainty in the expectation of entrepreneurs' profits, let alone commodity demand in the marketplace.

The editors and publisher apologize for the errors.

\section{REFERENCE}

Ahiakpor, James C. W. 2018. "Keynes, Mill, and Say's Law: A Comment on Roy Grieve's Mistaken Criticisms of Mill." Journal of the History of Economic Thought 40 (2): 267-273. 